\title{
Interdisciplinary management of central nervous system metastasis and neoplastic meningitis: recent developments and future perspectives
}

\author{
Ghazaleh Tabatabai ${ }^{1,13,14,17}$, Marilin Koch ${ }^{1,13,14}$, Cristiana Roggia'1,13,14, Juliane Ebert ${ }^{1,13,14}$, Claus Garbe ${ }^{2,14}$, \\ Friedegund Meier ${ }^{2,14,15}$, Sara Brucker ${ }^{3,14}$, Eva Maria Grischke 3,14, Diethelm Wallwiener 3,14, Robert Möhle ${ }^{4,14}$, \\ Lothar Kanz ${ }^{4,14,17}$, Walter Erich Aulitzky ${ }^{5}$, Ulrike Ernemann ${ }^{6,13,14}$, Christian laFougere $7,13,14,17$, \\ Konstantin Nikolaou ${ }^{8,14}$, Bernd Pichler ${ }^{9,14,17}$, Jens Schittenhelm ${ }^{10,13,14}$, Manuela Neumann ${ }^{10,13,14}$, \\ Falko Fend ${ }^{10,14}$, Stefan Czemmel ${ }^{1,14,16}$, Sven Nahnsen ${ }^{14,16}$, Frank Paulsen ${ }^{11,13,14}$, Daniel Zips ${ }^{11,13,14,17}$, \\ Maike van Lessen ${ }^{1,12,13,14}$, Hans-Otto Karnath ${ }^{12,13,14}$, Ulf Ziemann ${ }^{1,13,14}$, Hans-Georg Rammensee ${ }^{17,18}$, \\ Constantin Roder ${ }^{1,13,14}$, Marco Skardelly ${ }^{1,13,14}$, Jürgen Bernd Honegger ${ }^{1,13,14}$, Marcos Tatagiba ${ }^{1,13,14}$ \\ ${ }^{I}$ Interdisciplinary Division of Neuro-Oncology, Departments of Vascular Neurology and Neurosurgery, University Hospital Tübingen, Hertie \\ Institute for Clinical Brain Research, Eberhard Karls University, 72076 Tübingen, Germany. \\ ${ }^{2}$ Division of Dermato-Oncology, Department of Dermatology, University Hospital Tübingen, Eberhard Karls University, 72076 Tübingen, Germany. \\ ${ }^{3}$ Department of Gynecology and Ostetrics, University Hospital Tübingen, Eberhard Karls University, 72076 Tübingen, Germany. \\ ${ }^{4}$ Department of Internal Medicine (II), University Hospital Tübingen, Eberhard Karls University, 72076 Tübingen, Germany. \\ ${ }^{5}$ Department of Hematology and Oncology, Robert Bosch Hospital Stuttgart, Stuttgart, Germany, Comprehensive Cancer Center, Tübingen Stuttgart, Germany. \\ ${ }^{6}$ Department of Diagnostic and Interventional Neuroradiology, University Hospital Tübingen, Eberhard Karls University, 72076 Tübingen, Germany. \\ ${ }^{7}$ Department of Nuclear Medicine, University Hospital Tübingen, Eberhard Karls University, 72076 Tübingen, Germany. \\ ${ }^{8}$ Department of Diagnostic and Interventional Radiology, University Hospital Tübingen, Eberhard Karls University, 72076 Tübingen, Germany. \\ ${ }^{9}$ Department of Preclinical Imaging and Radiopharmacy, University Hospital Tübingen, Eberhard Karls University, 72076 Tübingen, Germany. \\ ${ }^{10}$ Department of Pathology and Neuropathology, University Hospital Tübingen, Eberhard Karls University, 72076 Tübingen, Germany. \\ ${ }^{\prime \prime}$ Department of Radiation Oncology, University Hospital Tübingen, Eberhard Karls University, 72076 Tübingen, Germany. \\ ${ }^{12}$ Division of Neuropsychology, University Hospital Tübingen, Hertie Institute for Clinical Brain Research, Eberhard Karls University, 72076 Tübingen, Germany. \\ ${ }^{13}$ Center for CNS tumors, Comprehensive Cancer Center Tübingen Stuttgart, Germany. \\ ${ }^{14}$ Center for Personalized Medicine, University Hospital Tübingen, Eberhard Karls University, Tübingen, Germany. \\ ${ }^{15}$ Center for Dermato-Oncology, University Hospital Dresden, Germany. \\ ${ }^{16}$ Quantitative Biology Center (QBiC), Eberhard Karls University, Tübingen, Germany, \\ ${ }^{17}$ DKTK, DKFZ partner site Tübingen. \\ ${ }^{18}$ Department of Immunology, Eberhard Karls University Tübingen, Germany.
}

Correspondence to: Prof. Ghazaleh Tabatabai, Interdisciplinary Division of Neuro-Oncology, Departments of Vascular Neurology and Neurosurgery, University Hospital Tübingen, Hertie Institute for Clinical Brain Research, Eberhard Karls University, 72076 Tübingen, Germany. E-mail: ghazaleh.tabatabai@uni-tuebingen.de

\section{A B S T R A C T}

The incidence of metastatic disease in the central nervous system (CNS) is rising. According to current estimates, up to a third of adult cancer patients will suffer from CNS metastasis. Clinical evidence-based data from prospective randomized trials are rare, however, because CNS metastasis patients were often excluded from clinical trial participation. The management of CNS metastasis patients is therefore rather ill-defined and an interdisciplinary challenge. Recent basic and translational science data have begun contributing to a more profound understanding of the molecular mechanisms leading to invasion of tumor cells into the CNS. This report reviews advances, challenges, and perspectives in this field.

Key words: Brain tumor; central nervous system metastases; interdisciplinary management

This is an open access article distributed under the terms of the Creative Commons Attribution-NonCommercial-ShareAlike 3.0 License, which allows others to remix, tweak, and build upon the work non-commercially, as long as the author is credited and the new creations are licensed under the identical terms.

For reprints contact: service@oaepublish.com

\begin{tabular}{|l|l|}
\hline \multicolumn{2}{|c|}{ Access this article online } \\
\hline Quick Response Code: & Website: \\
\hline & http://jcmtjournal.com \\
\cline { 2 - 2 } & \\
\hline
\end{tabular}

How to cite this article: Tabatabai G, Koch M, Roggia C, Ebert J, Garbe C, Meier F, Brucker S, Grischke EM, Wallwiener D, Möhle R, Kanz L, Auletzky WE, Ernemann U, La Fougere C, Nikolaou K, Pichler B, Schittenhelm J, Neumann M, Fend F, Czemmel S, Nahnsen S, Paulsen F, Zips D, Lessen MV, Karnath HO, Ziemann U, Rammensee HG, Roder C, Skardelly M, Honegger JB, Tatagiba M. Interdisciplinary management of CNS metastasis and neoplastic meningitis:recentdevelopments and future perspectives. J Cancer Metasta Treat 2016;2:163-75.

Received: 08-01-2016; Accepted: 09-03-2016. 


\section{INTRODUCTION}

Invasion of tumor cells from primary tumors of the central nervous system (CNS) to organs outside the CNS is a highly rare event. In contrast, invasion of tumor cells arising outside the CNS to brain, spinal cord, or cerebrospinal fluid (CSF) occurs frequently, leading to CNS tumor growth and neoplastic meningitis. Moreover, in approximately every tenth patient, the diagnosis of brain metastasis is the first sign of the cancer disease. ${ }^{[1]}$

CNS metastases are the most common intra-axial malignancies, accounting for more than $50 \%$ of all brain tumors, ${ }^{[2]}$ occurring in $20-40 \%$ of patients with cancer, and leading to symptoms during lifetime in about $60-75 \% .^{[3]}$ Autopsy series identified CNS metastases in $15-41 \%$ of patients with known primary cancers at the time of death. ${ }^{[4-8]}$ Most metastatic manifestations affect the brain parenchyma; $80 \%$ are found supratentorially and $20 \%$ infratentorially ( $15 \%$ cerebellum, $5 \%$ in the brain stem), with the spinal cord most infrequently involved. The incidence of single $v s$. multiple sites of CNS metastasis is approximately equal. ${ }^{[9]}$ In about $4-15 \%$ of patients with CNS disease, CSF is involved. ${ }^{[10]}$ Lung cancer, breast cancer, and melanoma are the primary malignancies that contribute to $80 \%$ of brain metastases. ${ }^{[7,11,12]}$ Moreover, there is a high incidence of asymptomatic CNS metastases, so it is hard to estimate their true prevalence. Current studies estimate that approximately a third of patients with cancer eventually develop brain metastases. ${ }^{[10]}$

Several reasons may explain the increase in incidence of brain metastases over the past decades: Certainly, the widespread use and improvements in new imaging technologies facilitates the detection of metastatic lesions. For example, magnetic resonance imaging (MRI) of the neuraxis is currently used for the examination of approximately $60-70 \%$ of patients with cancer; 20 years ago, it was used in $2 \%$ of cancer patients. ${ }^{[13]}$ The global increase in cancer prevalence is another contributing factor, especially the increase in cancers that have a tendency to invade the CNS, such as lung cancer. Moreover, the introduction of targeted therapies that have limited bioavailability in the CNS might also have resulted in an increase of CNS metastases (e.g. the treatment of human epidermal growth factor receptor protein 2(HER2)-positive breast cancer with trastuzumab, a compound with limited penetration from the blood to the CSF). ${ }^{[1,15]}$

Neoplastic meningitis (also referred to as meningeosis neoplastica or, based on the underlying tumor, as meningeosis carinomatosa, gliomatosa, or lymphomatosa) is a spread of tumor cells into the subarachnoid space. It is found in approximately $5-10 \%$ of all patients with malignant tumors and is a condition frequently diagnosed in late stage cancer. ${ }^{[16]}$ The most common associated primary tumors are lung cancer, breast cancer, melanoma and lymphoma and leukemia. ${ }^{[17]}$

Patients with CNS metastases present with rather unspecific clinical symptoms. Headaches (40-50\%), focal neurological deficits (30-40\%), and seizures (15-20\%) are the most common presenting symptoms. In leptomeningeal disease many symptoms are caused by an increased intracranial pressure mainly due to hydrocephalus, which leads to nausea and vomiting, neck and back pain, and confusion. ${ }^{[3]}$

\section{MOLECULAR MECHANISMS OF CENTRAL NERVOUS SYSTEM METASTASIS FORMATION AND MAINTENANCE}

Cancers that metastasize to the CNS need to undergo multiple steps, including detachment from the primary site, invasion, intravasation into the bloodstream, extravasation, survival, and proliferation. Even with different primary tumor origins, invasion and proliferation into the CNS appears to be associated with similar molecular programs and is highly supported and maintained by the tumorassociated brain microenvironment. ${ }^{[18]}$

First, the growth of metastatic brain tumors is critically dependent on angiogenesis, ${ }^{[19]}$ so therapies targeting this process might be important in the prevention or management of brain metastases. In a mouse model of brain metastases [HER2-amplified breast cancer cells in an orthotopic xenografting of human BT-474 cells], extracranial disease was successfully controlled using the HER2 inhibitors trastuzumab or lapatinib, but tumor control with monotherapy in the brain failed. By adding anti-VEGFR2 antibodies, however, tumor growth in the brain was better controlled, leading to improved survival, especially with a combination of lapatinib, trastuzumab, and anti-VEGFR2 antibody treatment. ${ }^{[20]}$

Second, astrocytes are intimately involved in maintaining normal homeostasis of the brain microenvironment, accomplished through transport of nutrients to the neurons and facilitation of neural signal transduction. In fact, activated astrocytes induced upregulation of survival genes. These mechanisms usually protect injured neurons from apoptosis, but can be abused by tumor cells (e.g. for protection from cytotoxic effects of chemotherapeutic agents). ${ }^{[21,22]}$ A very interesting study on the impact of astrocyte-derived reshaping of the brain microenvironment was recently published by Zhang and colleagues: Mouse tumor cells lost PTEN expression only after dissemination to the brain, but not to other organs, and PTEN levels in PTEN-loss brain metastatic tumor cells were again rescued after leaving the brain microenvironment. This brain microenvironment-dependent plasticity of PTEN expression is epigenetically regulated by astrocyte-derived exosomes mediating an intercellular transfer of PTENtargeting microRNAs to metastatic tumor cells. As a 
result of this adaptive PTEN loss, brain metastatic tumor cells released more chemokine CC chemokine ligand 2, leading to recruitment of IBA1-expressing myeloid cells and further enhancement of the growth and maintenance of brain metastases. ${ }^{[23]}$

Infiltrating inflammatory host cells, including tumorinfiltrating lymphocytes or myeloid cells, are a third key component shaping the tumor microenvironment and correlating with patients' survival times in several extracranial malignancies. ${ }^{[24]}$ These cells significantly change their functional characteristics under the influence of high-grade glioma, ${ }^{[25]}$ indicating that they might also play a role for supporting CNS metastatic growth. Clinicopathological correlations of associated lymphocytic infiltrates indicate a beneficial outcome for CNS immune response. ${ }^{[2]}$ Two functional phenotypes of tumorassociated macrophages have been proposed: the M1 and the M2 phenotype. While M1 is characterized by tumorsuppressive functions, the M2 may have more tumorpromoting functions, including suppression of immune responses and promotion of adaptive immune response and migration/invasion. ${ }^{[25]}$ However, recent studies suggest that this dichotomy does not completely reflect the situation in brain tumors. ${ }^{[27]}$

In recent years, high-throughput technologies have evolved significantly. Thus, molecular tumor profiling (e.g. by Nextgeneration sequencing, panel sequencing) for identifying molecular targets is in principle feasible in the short term. Data on the molecular characteristics of CNS metastases have only recently been acquired. This might be due to the fact that CNS metastatic tissues are only available from patients who are eligible for neurosurgical resection. Because craniotomies are not indicated in all patients with CNS metastases (see below), a systematic analysis of the molecular differences between CNS metastases and matched primary tumors or between CNS metastases and extracranial metastases remains challenging. Molecular profiling of matched CNS and extracranial metastases in smaller series of melanoma patients showed that CNS metastases distinguished themselves through specific molecular differences in the activation of the PI3K/mTOR/ Akt or HER2 or kirsten rat sarcoma (KRAS) pathway. ${ }^{[28-31]}$ These studies highlight, for example, the potential of adding PI3K inhibitors or mTOR inhibitors as adjunct targeted therapy in the treatment of CNS metastases.

\section{TREATMENT STRATEGIES NEED A PROFOUND INTERDISCIPLINARY DIAGNOSTIC WORKUP}

In addition to the staging of extracranial disease, a thorough neurological workup including neurological examination, neurocognitive assessments, neuroimaging, and a spinal tap is in principle indicated in all patients with established malignant disease and suspected brain metastases.
Depending on clinical symptoms and neuroradiological features, one single spinal tap or up to three spinal taps can be considered. If, for example, clinical symptoms strongly suggest an underlying meningeomatosis, a single lumbar puncture might not be enough to detect atypical cells in the CSF, so serial lumbar punctures might be necessary. Diagnostic workup of the CSF includes analyses of opening pressure, protein, glucose, and lactate levels as well as cytology and immunocytology.

Standard MRI exams include T1-weighted images with or without contrast enhancement, T2-weighted imaging, and FLAIR sequences. Differential diagnosis of brain metastases includes malignant gliomas and lymphomas or nonneoplastic conditions, such as abscess, infections, demyelinating diseases, and vascular lesions. Recently, the Response Assessment in Neuro-Oncology Brain Metastases (RANO-BM) working group has proposed criteria for a harmonization of the assessment of CNS metastases. ${ }^{[32]}$ This might contribute to a standardization of techniques and assessment tools, particularly important in the era of targeted compounds. It is not yet entirely clear to what extent and how novel targeted therapies (e.g. immunotherapies and kinase inhibitors) will alter imaging characteristics. The recently published recommendations of the RANO-BM working group provide a guideline to differentiate imaging alterations during immunotherapies in brain tumors. ${ }^{[33]}$ Innovative and advanced neuroimaging techniques will certainly gain even more importance. Examples include the addition of diffusion-weighted MRI (DW-MRI), perfusion MRI, proton magnetic resonance spectroscopy (MRS), and various amino acid tracers in positron emission tomography (PET). These techniques might be especially relevant to meet the challenges of disease monitoring (e.g. the discrimination of radiation necrosis from recurrent tumor might be challenging on MRI since both conditions present with contrast enhancement on T1-weighted MR images, and the pattern of abnormal enhancement closely mimics that of a recurrent brain metastasis). ${ }^{[34]}$ In fact, small studies with perfusion MRI using CBV analysis showed the potential to differentiate between radiation necrosis and tumor recurrence with good sensitivity and specificity. ${ }^{[35]}$ Nuclear medicine techniques might contribute to answering this critical question. While an fludeoxyglucose (FDG) tracer was not sensitive enough to differentiate vital brain metastases from unspecific nontumor changes related to therapy, ${ }^{[36]}$ the amino-acid PET tracer ${ }^{11} \mathrm{C}$-methionine showed higher tumor-to-lesion uptake ratios in patients with recurrent metastases/glioma after radiation treatment than in patients with radiation necrosis. ${ }^{[37]}$ Furthermore, the combination of two amino acid tracers (FET and MET) identified treatment-related changes with high sensitivity and specificity. ${ }^{[38]}$

The blood-brain-barrier is often mentioned as a challenge for diagnosis and therapy. In a very interesting preclinical study using mouse models of small metastatic breast 
tumors, infusions of recombinant human tumor necrosis factor induced selective permeabilization of the blood-brain barrier to imaging tracers at sites of brain metastases. This method enabled the detection of smaller tumors that had been invisible using standard imaging techniques. Notably, this strategy even increased the delivery of radiolabeled trastuzumab to these metastatic lesions, ${ }^{[39]}$ demonstrating the translational potential of similar approaches for theranostics.

\section{THE ESTIMATION OF PROGNOSIS IS IMPORTANT FOR CLINICAL MANAGEMENT}

The most widely established risk stratification scores are the Recursive Portioning Analysis (RPA), the Graded Prognostic Assessment (GPA), and Diagnosis Specific Graded Prognostic Assessment (DS-GPA) [Table 1]. [40-43] Definitely, the presence of neoplastic meningitis in patients with solid tumors indicates a poor prognosis. Negative prognostic factors associated with leptomeningeal tumor cell dissemination are low Karnofsky performance status (KPS), increased age, uncontrolled intracranial pressure, low glucose levels, and high protein levels. ${ }^{[44-46]}$

RPA divides patients into three categories based on KPS, age, and primary tumor control, with patients in group I having a better prognosis than patients in group III. ${ }^{40]}$ The GPA evaluates the prognosis of patients with brain metastases based on the primary tumor diagnosis. ${ }^{[42]}$ Histology carries prognostic significance, along with other subcategories (e.g. age and extracranial disease in lung cancer patients, or number of metastases in melanoma patients). Tumor subtype based on HER2/ER/PR status and age is prognostic for breast cancer and is expanded upon with a specific breast-GPA, currently in use in clinical trials. ${ }^{[43]}$ Other prognostic scores were defined ${ }^{[47]}$ and are summarized in Table 1. In large retrospective studies of melanoma patients with brain metastases, poor prognostic factors associated with worse survival were: $>3$ parenchymal lesions, leptomeningeal disease, brain lesions developing concurrently with extracranial disease or while on systemic therapy for extracranial disease, poor performance status (KPS $<70 \%$ ), elevated pretreatment LDH levels, and RPA class III. ${ }^{[48,49]}$

Table 1: Prognostic scores

\begin{tabular}{|c|c|c|c|}
\hline \multicolumn{4}{|c|}{ Recursive partioning analysis } \\
\hline \multirow[t]{5}{*}{ Class } & I & II & III \\
\hline & Age $<65$ & All patients not in Class I or class III & $\mathrm{KPS}<70 \%$ \\
\hline & $\mathrm{KPS}>70 \%$ & & \\
\hline & Stable primary tumor & & \\
\hline & No extracranial metastases & & \\
\hline \multicolumn{4}{|c|}{ Basic score for brain metastases } \\
\hline Score & $\mathbf{0}$ & 1 & \\
\hline KPS & $50-70 \%$ & $80-100 \%$ & \\
\hline Control of primary tumor & No & Yes & \\
\hline Extracranial metastases & Yes & No & \\
\hline \multicolumn{4}{|c|}{ Score index for radiosurgery } \\
\hline Score & $\mathbf{0}$ & 1 & 2 \\
\hline Age (years) & $>60$ & $51-59$ & $<50$ \\
\hline KPS & $<50 \%$ & $60-70 \%$ & $80-100 \%$ \\
\hline Systemic disease & Progressive & Stable & $\begin{array}{l}\text { Complete response or no } \\
\text { evidence for disease }\end{array}$ \\
\hline Number of lesions & $>3$ & 2 & \\
\hline Volume of largest target lesion & $>13 \mathrm{~mL}$ & $5-13 \mathrm{~mL}$ & $<5 \mathrm{~mL}$ \\
\hline \multicolumn{4}{|c|}{ Graded prognostic assessment } \\
\hline Score & $\mathbf{0}$ & 0.5 & 1.0 \\
\hline Age & $>60$ & $50-59$ & $<50$ \\
\hline KPS & $<70 \%$ & $70-80 \%$ & $90-100 \%$ \\
\hline CNS metastases (no.) & $>3$ & $2-3$ & 1 \\
\hline Extracranial metastases & Present & - & None \\
\hline \multicolumn{4}{|c|}{ Diagnosis-specific graded prognostic assessment } \\
\hline \multicolumn{4}{|c|}{ i) NSCLC/SCLC } \\
\hline Score & 0 & 0.5 & 1.0 \\
\hline Age & $>60$ & $50-60$ & $<50$ \\
\hline KPS & $<70 \%$ & $70-80 \%$ & $90-100 \%$ \\
\hline Extracranial metastases & Present & - & Absent \\
\hline \multirow{2}{*}{\multicolumn{4}{|c|}{ ii) Melanoma/RCC }} \\
\hline & & & \\
\hline Score & 0 & 1 & 2 \\
\hline KPS & $<70 \%$ & $70-80 \%$ & $90-100 \%$ \\
\hline CNS metastases (no.) & $>3$ & $2-3$ & 1 \\
\hline \multicolumn{4}{|l|}{ iii) Breast/GI cancer } \\
\hline Score $\quad 0$ & 1 & 2 & 4 \\
\hline$<70 \%$ & $70 \%$ & $90 \%$ & $100 \%$ \\
\hline
\end{tabular}

CNS: central nervous system; KPS: karnofsky performance status; NSCLC: non small-cell lung cancer 
The prognostic indices certainly play an important role in assessing the risk/benefit ratio and providing realistic advice and expectations to patients. For example, patients with poor prognosis can be offered supportive care, and those with good prognosis can be offered multimodality treatment. The prognostic scores might play a vital role in designing clinical trials as well.

Information about variables on neuroimaging, in addition to the pure number of brain metastases, might be valuable extensions to currently established prognostic scores. Spanberger and colleagues found a significant correlation between a small brain edema with an invasive tumor growth pattern, a low neo-angiogenic activity, and a low expression of HIF1a. These findings were associated with a shorter overall survival. ${ }^{[50]}$ Further, high DW-MRI hyperintensity correlated significantly with a high amount of interstitial reticulin deposition, and this was again associated with lower survival. ${ }^{[51]}$ Similarly, pre-operative DW-MRI characteristics of cerebral metastases and their peritumoral region in 76 patients were related to patient outcome..$^{[52]}$

\section{THERAPEUTIC APPROACHES TO CENTRAL NERVOUS SYSTEM METASTASIS}

CNS metastases are, of course, a heterogeneous group with varied response to treatment and survival. Conventional treatment options usually include a combination of steroids, surgery, and radiation. Cytotoxic chemotherapy has had a limited role in the treatment of brain metastases, probably because CNS metastases often arise from heavily pretreated primary tumors and may thus have already acquired resistance to chemotherapeutics. In addition, the impaired blood-brain barrier penetration of some agents might further reduce their bioavailability in the CNS. Therapeutic decisions mainly depend on several factors related to patient clinical status (neurological deficit, neurocognitive deficit, general condition, comorbidities, etc.), primary disease status, extracranial metastatic disease, and CNS tumor characteristics (number, radiological aspect, size, and location). ${ }^{[40]}$ Median overall survival times after occurrence of CNS metastases might be predicted by biomarkers as shown for LDH elevation in melanoma CNS metastases. ${ }^{[48]}$ All relevant clinical factors need to be taken into account to identify the best therapeutic strategy among the available therapeutic options. We outline the currently available local and systemic therapeutic options in the following paragraphs.

\section{LOCAL THERAPEUTIC STRATEGIES: NEUROSURGICAL INTERVENTION AND RADIATION THERAPY}

Neurosurgical intervention and radiation therapy are currently the main modalities in the therapy of symptomatic CNS metastases. New surgical modalities have expanded the indication and spectrum of tumors that can be successfully removed. Since the introduction of intraoperative monitoring and development of less invasive strategies (e.g. microsurgery, endoscopic surgery, intraoperative navigation, ultrasound, and intraoperative MRI), surgical removal of brain metastases even in deepseated and elusive areas has become feasible without increased morbidity. To date, the strongest evidence for a survival benefit from surgery is for single CNS metastases. ${ }^{[53]}$ In 1996, Mintz et al. ${ }^{[54]}$ did not confirm a positive impact of surgery on overall survival in these patients. However, only $21.4 \%$ of patients in this study had a controlled extracerebral disease, and none of the patients had brain MRI assessment; therefore, comparability with other studies is rather limited. In a retrospective study of treatment modalities in 1,292 patients with CNS metastasis of lung cancer, breast cancer, and melanoma, Lagerwaard et al. ${ }^{[55]}$ demonstrated an increase of median OS of 1.3 months in patients who received best supportive care only, 3.6 months in patients who received RT, and 8.9 months in patients who received a combination of surgery and RT. Similar median OS benefits were also shown in a retrospective study of 1,137 melanoma patients who received best supportive care (2.1 months), RT (3.4 months), surgery (8.7 months), or combined RT and surgical resection. ${ }^{[56]}$

Benefits of surgery include the ability to establish a tissue diagnosis and an immediate decrease of tumor mass, particularly of masses in the posterior fossa. Nevertheless, patients who might benefit from surgical resection must be carefully selected. Predictors that favor a surgical benefit include: single or few metastases, tumor location, surgical accessibility, KPS $>70$, patient age $<65$ years, local mass effect, control of extracranial disease, and absence of leptomeningeal involvement. ${ }^{[57]}$ Based on the therapy oncology group database, patients of RPA class I are likely to benefit from surgery, whereas patients of RPA class III are not. ${ }^{[40]}$ The primary goal of surgery is either macroscopic gross total resection or decompression dependent on the aforementioned predictors. Intraoperative neurosurgical techniques to maximize resection (e.g. image-guided surgery, ${ }^{[58]}$ ultrasonography, ${ }^{[59]}$ and introduction of fluorescence-guided surgery ${ }^{[60]}$ ) and to minimize neurological deficits by electrophysiological techniques $^{[58]}$ improved the likelihood of complete and safe removal of metastases. A combination of surgery plus radiation in patients with up to three CNS metastases can improve survival and preserve functional independence, as outlined in two prospective studies $^{[61,62]}$ and three retrospective studies. ${ }^{[63-65]}$ Several criteria -- including tumor location, medical comorbidities, extracranial disease, and performance status -- may impact individual consideration and risk assessment for surgical resection. This is particularly relevant because evidence from studies in high-grade glioma surgery indicates that a new 
Table 2: Overview of targeted compounds for central nervous system metastases that are outlined in the text

\begin{tabular}{|c|c|c|}
\hline Molecular target & Compound & Compound characteristics \\
\hline \multirow[t]{5}{*}{ HER2 } & Trastuzumab & Humanized $\mathrm{mAb}$ targeting the extracellular domain of HER2 \\
\hline & Trastuzumab emantasine & $\begin{array}{l}\text { Antibody-drug conjugate; the antibody targeting HER } 2 \text { is conjugated with } \\
\text { an antimicrotubule agent that is only released in HER2 } 2^{+} \text {target cells }\end{array}$ \\
\hline & Lapatinib & Small molecule tyrosine kinase inhibitor that dually targets HER1 and \\
\hline & & HER2, binding to the intracellular domain \\
\hline & Neratinib & $\begin{array}{l}\text { Irreversible inhibitor targeting the catalytic domain of EGRF, HER2, and } \\
\text { HER4 }\end{array}$ \\
\hline \multirow[t]{2}{*}{ EGFR } & Gefitinib & Inhibitor of EGFR \\
\hline & Erlotinib & Inhibitor of EGFR \\
\hline \multirow[t]{3}{*}{ ALK } & Crizotinib & Inhibitor of ALK \\
\hline & Ceritinib & Inhibitor of ALK \\
\hline & Alectinib & Inhibitor of ALK \\
\hline \multirow[t]{2}{*}{ BRAF } & Vemurafenib & Selective inhibitor of mutated $\mathrm{BRAF}^{\mathrm{V} 600 \mathrm{E}}$ \\
\hline & Dabrafenib & Inhibitor of mutated BRAF, wild-type BRAF, and CRAF \\
\hline CTLA4 & Ipililumab & Antibody targeting CTLA-4 \\
\hline \multirow[t]{2}{*}{ PD-1 } & Pembrolizumab & Antibody targeting PD-1 receptor \\
\hline & Nivolumab & Antibody targeting PD-1 receptor \\
\hline
\end{tabular}

ALK: anaplastic lymphoma kinase; BRAF: serine/threonine-protein kinase B-Raf; CTLA: cytotoxic T-lymphocyte-associated antigen; HER: human epidermal growth factor receptor protein; EGFR: epidermal growth factor; PD: programmed death

postoperative neurological deficit decreases survival up to 3-4 months, and any substantial postoperative complication negatively affects functional status and the patient's ability to undergo subsequent radiation treatment, both of which are crucial factors in determining survival. ${ }^{[66]}$

The main modalities in radiation therapy include stereotactic radiotherapy and whole brain radiation therapy. Stereotactic radiotherapy alone might be considered for patients who have a controlled systemic disease and a limited number of CNS metastases whose size is less than $3 \mathrm{~cm}$. A combination of stereotactic and whole brain radiotherapy has been investigated in large clinical trials. There was no difference in overall survival, but the addition of whole brain radiation therapy significantly improved local and distant control. ${ }^{[9,67]}$ Yet, patients treated with whole brain and stereotactic radiation therapy were at higher risk of a decline in learning and memory. Of note, neurocognitive testing was only performed once at 4 months in this trial. ${ }^{[68]}$ Novel concepts of whole brain radiation therapy with an avoidance of the hippocampal region might lead to new opportunities in this treatment modality.

Radionecrosis can occur, typically within the first year after stereotactic radiotherapy. The differentiation between tumor progression and radionecrosis might be difficult, as mentioned earlier. Treatment recommendations for radiosurgery radionecrosis include bevacizumab and/or steroids. ${ }^{[69]}$

Regarding a refinement of treatment planning for radiation therapy, the value of amino acid PET in stereotactic radiotherapy treatment planning for focal recurrence at a previously irradiated site of a brain metastasis was evaluated. In 88 patients, the authors found that the total irradiation volume was significantly smaller in the PET group and that the median survival time was significantly longer in the PET group (18.1 months) than in the MRI planning group (8.6 months). ${ }^{[70]}$

\section{CYTOTOXIC CHEMOTHERAPY: NO CONVENTIONAL STANDARD REGIMEN FOR CENTRAL NERVOUS SYSTEM METASTASES}

To date, standard cytotoxic chemotherapy regimens have not been defined for the treatment of CNS metastases. Instead, inoperable patients are treated using the same cytotoxic chemotherapy employed for the treatment of extracranial disease. Alternatively, cytotoxic agents with good CNS penetration (such as topotecan, irinotecan, procarbazine, and carboplatin, temozolomide, or fotemustine) are also employed for empirical therapy, even in cases in which these agents are not the standard therapy for the primary tumor site. Pharmacological treatments for intrathecal therapies are ill-defined, too.

\section{INTRATHECAL TREATMENT THERAPY FOR TARGETING THE CEREBROSPINAL FLUID}

Intrathecal administration of drugs aims at targeting tumor cells in the CSF efficiently by circumventing the blood-CSF barrier while omitting systemic toxicity. Treatment can be done by repetitive lumbar punctures or through intraventricular catheter systems (i.e., Rickham or Ommaya reservoir). Among the drugs available for intrathecal treatment, methotrexate (MTX) and cytarabine are most frequently used. Alternatively, thiotriethylenephosphoramide has been approved in some countries. Liposomal cytarabine is a sustained-release form of cytarabine and was compared with MTX in a controlled trial in patients with solid tumors and leptomeningeal carcinomatosis. Patients who were treated with liposomal cytarabine experienced a longer time until neurological progression. However, there was no difference in overall survival. ${ }^{[71]}$ Liposomal cytarabine is associated with an increased risk for radiculitis and arachnoiditis. This might be prevented by prophylactic dexamethasone application. 
Supportive therapy aims at symptom relief. Steroids may help to decrease symptom burden similar to the situation in solid tumor manifestations in the brain. ${ }^{\text {72] }}$

\section{TARGETED THERAPIES ARE AVAILABLE FOR A SUBSET OF CENTRAL NERVOUS SYSTEM METASTASES}

With increasing insight into molecular alterations and improved CNS penetration of targeted compounds, some specific molecular-targeted compounds are available that can also be applied in CNS metastases [Table 2]. We focus here on breast cancer, lung cancer, and melanoma.

\section{Breast cancer}

HER 2 is overexpressed in up to $30 \%$ of breast cancers. ${ }^{[73]}$ A retrospective analysis of 9,524 women in the pretrastuzumab era identified HER2 expression as a risk factor for brain metastases ${ }^{[74]}$ with an incidence of CNS metastases in HER2-positive patients twice that of unselected breast cancer patients. Additionally, an increasing percentage of patients develop brain metastases, whereas their systemic disease is controlled using HER2-directed therapies. ${ }^{[75]} \mathrm{A}$ retrospective case series reported 23 of 93 (25\%) patients developed brain metastases after trastuzumab therapy, and $78 \%$ of those patients had stable or better systemic disease. A meta-analysis using data from three large phase III trials indicated the incidence of CNS disease was significantly higher in the trastuzumab-treated patients. ${ }^{[15]}$ Trastuzumab's high molecular weight, approximately 700 times that permitted by the blood-brain barrier, may create a sanctuary site in the CNS for HER2-positive tumors, and its limited CSF bioavailability hinders efficacy in treating brain metastases. ${ }^{[14]}$ Lapatinib is a dual HER1 and HER2 inhibitor that is administered orally. A single-arm phase II trial evaluated the activity of lapatinib plus capecitabine in 45 patients with HER2-positive breast cancer and brain metastases before Whole brain radiation therapy (WBRT). The CNS response rate was $67 \%$ with a median time to progression of 5.5 months. ${ }^{[76]}$ Trastuzumab emtansine (TDM1) is an antibody-drug conjugate incorporating the human epidermal growth factor receptor 2 (HER2)-targeted antitumor properties of trastuzumab with the cytotoxic activity of the microtubule-inhibitory agent DM1. The antibody and the cytotoxic agent are conjugated by means of a stable linker. ${ }^{[77]}$ The incidence of central nervous system (CNS) metastases after treatment with trastuzumab emtansine (T-DM1) versus capecitabine-lapatinib (XL), and treatment efficacy among patients with pre-existing CNS metastases in the phase III EMILIA study was analyzed in a retrospective study. In this retrospective, exploratory analysis, the rate of CNS progression in patients with HER2-positive advanced breast cancer was similar for T-DM1 and for XL. In patients with treated, asymptomatic CNS metastases at baseline, T-DM1 was associated with significantly improved OS compared with XL. ${ }^{[78]}$
Neratinib is an orally administered inhibitor of the ErbB receptor tyrosine kinase with antitumor activity in advanced HER2-positive breast cancer. ${ }^{[79]}$ A phase II trial is currently underway for patients with HER2-positive breast cancer and brain metastases (NCT01494662). Further aspects of CNS metastases in the breast are outlined in a recent review. ${ }^{[80]}$

\section{Non small-cell lung cancer}

With the discovery of targetable molecular alterations in the treatment of non small-cell lung cancer (NSCLC), patients with newly diagnosed disease are currently stratified based on molecular alterations of several genes in the primary tumor, including the epidermal growth factor receptor (EGFR), Kirsten rat sarcoma viral oncogene homolog (KRAS), and translocations involving the echinoderm microtubule-associated protein like 4 (EML4) analastic lymphoma kinase (ALK) genes. ${ }^{[81]}$ In a retrospective study of 89 patients with NSCLC treated with stereotactic radiation therapy for CNS metastases, the addition of targeted therapies was associated with significantly better outcomes. Patients treated with targeted therapy against EGFR or ALK had a median survival of 21 months compared with 11 months for patients who did not receive targeted therapy. ${ }^{[81]}$ EGFR mutations are present in 10-25\% of NSCLC. EGFR mutations in patients with brain metastases may be more common; two reports found EGFR mutations to be present in $63 \%$ and $50 \%$ of patients, raising the question whether EGFR mutations lead to an increased risk of developing brain metastases similar to HER2 overexpression in breast cancer. ${ }^{[82]}$ Patients with ALK activation, on the other hand, had no increased risk of brain metastases but did show a higher frequency of liver metastases. ${ }^{[83,84]}$

Gefitinib and erlotinib are oral compounds and irreversible inhibitors of the intracellular domain of EGFR. Gefitinib is FDA-approved for NSCLC with EGFR mutations. Erlotinib is approved for locally advanced or metastatic NSCLC that has failed at least one prior chemotherapy regimen or for maintenance treatment for locally advanced metastatic NSCLC whose disease has not progressed after four cycles of platinum-based first-line chemotherapy. There is concern about poor $\mathrm{BBB}$ penetration of these agents as CNS response rates are disproportional to systemic response rates. Serum to CSF comparisons for gefitinib revealed only about $1 \%$ of the serum dose represented in the CSF. ${ }^{[85]}$ Both drugs are near the $400 \mathrm{kDa}$ molecular weight range, with the $\mathrm{BBB}$ retaining selectivity for molecules greater than 200-400 kDa. Despite concerns for optimal bioavailability, gefitinib and erlotinib have been investigated in first-line palliative and combination settings. Two phase II trials for tyrosine-kinase inhibitors (TKI) in the first-line setting include data on patients with CNS metastases. ${ }^{[86,87]}$ Both studies do not include sequencing data for EGFR mutations but instead use the clinical indicator of never-smokers. Lee et al. ${ }^{[86]}$ reported 36 never-smoker patients including 10 patients with synchronous brain metastases. Seven of ten patients demonstrated an intracranial objective response to 
gefitinib, one patient had stable disease, and two patients had progressive disease after a median of 48-week followup period. Kim et al. ${ }^{[87]}$ reported 23 never-smoker patients with synchronous brain metastases with a response rate to either gefitinib or erlotinib of $69 \%$ and a disease control rate of $82 \%$. The median overall survival was 18.8 months, and time to salvage WBRT averaged 19.3 months.

Further evidence for first-line TKI comes from a retrospective analysis of 155 patients screened for EGFR mutations. ${ }^{[88]}$ The rate of CNS progression was lower in EGFR-mutant patients with advanced NSCLC treated initially with erlotinib or gefitinib compared with upfront cytotoxic chemotherapy $(33 \%$ vs. $48 \%)$ at a median follow-up of 25 months, supporting a role for these drugs in prevention of CNS metastases. Median overall survival, on the order of 30 months, was not different between the two groups.

Erlotinib in combination with WBRT was evaluated in a prospective phase II trial in 40 patients with brain metastases from NSCLC regardless of EGFR status. The overall response rate was $86 \%$ and the median overall survival was 11.8 months. Of these 40 patients EGFR status was known in 17 patients. Interestingly, patients negative for EGFR mutations had a median overall survival of 9.3 months, whereas patients who were positive for EGFR mutations had a median overall survival of 19.1 months. ${ }^{[89]}$ The clinical benefit and feasibility of targeting ALK was demonstrated first with the multitargeted tyrosine kinase inhibitor crizotinib that competitively binds to the ATPbinding pocket of the ALK and MET tyrosine kinases and inhibits phosphorylation of activated ALK. This was subsequently confirmed in phase II and III trials. ${ }^{[90-92]}$ The ability of ALK-directed therapies to control and prevent the development of CNS metastases remains incompletely studied, with early reports suggesting inefficient CSF penetration of crizotinib. ${ }^{[93-95]}$

Ceritinib is a second-generation ALK inhibitor with increased activity against common ALK point mutations. The activity of ceritinib in ALK + NSCLC has been confirmed in phase I and II studies. Larger head-to-head trials such as the phase III, ALEX "trial comparing alectinib to crizotinib will directly investigate PFS in the CNS and may provide further information to inform treatment decisions for $\mathrm{ALK}+$ patients with brain metastases.

\section{Melanoma}

Activating BRAF mutations affect up to $60 \%$ of melanoma patients; more than $95 \%$ are the p.V600E mutation, with the remainder largely being p.V600L. Constitutive BRAF signaling activates the mitogen-activated protein kinase (MAPK) pathway. ${ }^{[96]}$ Vemurafenib is an FDAapproved BRAF inhibitor. In a pilot study of 24 patients with melanoma metastatic to the CNS treated with vemurafenib, median PFS was 3.9 months, and median OS was 5.3 months. An overall partial response rate at both intracranial and extracranial sites was achieved in $42 \%$, and stable disease was achieved in $38 \% .{ }^{[97]}$ Further data are available from individual cases ${ }^{[98]}$ and population-based studies. ${ }^{[99]}$ New trials with CNS metastases are ongoing. Dabrafenib is an oral ATP-competitive inhibitor of BRAF kinase. A multicenter clinical trial evaluated dabrafenib in 172 patients both with and without prior brain therapy for BRAF-mutated melanoma metastatic to the brain with confirmed p.V600X mutation. ${ }^{[100]}$ The primary outcome measure was overall response rate observed to be $29 / 74$ $(39.2 \%)$ in patients without prior brain therapy and $20 / 65(30.8 \%)$ in patients with prior brain therapy. Thus, dabrafenib was helpful in patients with both new and pretreated brain metastases. Duration of response was 20.1 weeks for patients without prior brain treatment and 28.1 weeks for patients with prior brain treatment. Median overall survival was 33 weeks in patients without prior brain therapy and 31 weeks with prior brain therapy.

Resistance to therapy with BRAF kinase inhibitors is associated with a reactivation of the MAPK pathway. Consequently, the combination of BRAF and MEK inhibitor was assessed and showed increased efficacy compared to BRAF monotherapy alone. ${ }^{[101]}$

Current immunotherapy approaches focus mainly on checkpoint inhibitors Ipililumab and PD1/PDL1 inhibition. Ipililumab is a humanized monoclonal antibody against cytotoxic T lymphocyte antigen-4 (CTLA-4); it shows activity in melanoma brain metastasis, particularly if asymptomatic, by improving overall survival. ${ }^{[8,102,103]} \mathrm{A}$ phase 2 study of ipilimumab and fotemustine showed an overall immune disease control rate of $50 \%$ and median progression-free survival of 4.3 months, with increased incidence in hematological and nonhematological toxicity. Clinical trials for the assessment of immune checkpoint inhibition strategies in CNS metastases are ongoing.

\section{QUALITY OF LIFE AND NEUROCOGNITION}

The systematic assessment of neurocognitive function is often neglected in clinical routine but is crucial, mainly because neurocognitive function is a key feature of quality of life for patients. It is important to raise awareness and encourage more frequent use of neurocognitive monitoring tools (not only in large centers) as a regular part of the diagnostic workup. Certainly, there are multiple reasons for cognitive decline in patients with CNS metastases, including the neuroanatomical location of the lesions, symptomatic seizures, depression, distress, and potentially also the effects of neurotoxic systemic therapies and whole brain radiation therapy. It is notable that corticosteroids are a very common cause of neurocognitive decline. Steroid-induced changes in mood and sleep certainly affect cognitive function, leading to measurable effects on 
declarative memory and even to decreased hippocampal volumes. ${ }^{[104]}$ The severity of memory impairment is correlated to dose and duration of use..$^{[105]}$

Primary prevention strategies might include the implementation of hippocampal-sparing whole brain radiation therapy, prophylactic use of the N-methyl-Daspartate receptor modulator memantine, or blocking the RAAS cascade. Assessment and treatment of depression is an important strategy, including appropriate pharmaceutical or psychological treatments.

\section{FUTURE PERSPECTIVES}

With increasing incidence of CNS metastases, an improvement of existing treatment strategies is urgently needed. Important steps for meeting this important epidemiological challenge include systematic interdisciplinary multiprofessional treatment teams, thorough biosampling and biobank studies for the establishment of further biomarkers or therapeutic targets, innovative imaging tools, and innovative clinical trial designs with meaningful endpoints including survival, quality of life, and neurocognitive assessments. Any extension of progression-free or overall survival for these patients will only be meaningful if quality of life and neurocognition can be preserved. There is rising need for further definition of reliable molecular/genetic tumor markers to be implemented in routine pathology/ neuropathology diagnostics, to catch up to increasing insights into molecular heterogeneity of cancer and its interaction with the local microenvironment.

An important future challenge will be to implement affordable investigations of the molecular and cellular components of the tumor microenvironment. In this regard, it will be increasingly important to visualize and monitor the expression of molecules and cell motion as well as to enhance the technical possibility of calculating cellularity, vessel permeability, vascular perfusion, metabolic and physiological changes, apoptosis, and inflammation prior to and during the course of therapy. A multimodal imaging algorithm is likely to improve sensitivity and specificity to meet these requirements. Certainly, novel multimodal algorithms will have to be prospectively investigated in multicenter trials for validation and standardization.

Since serial tissue biopsies are rarely clinically justified in CNS metastases, and in light of new upcoming targeted treatment options, noninvasive tools to measure drug penetration, pharmacodynamic effects, and efficacy are becoming increasingly important. Examples include PETbased approaches for noninvasive measuring of drug uptake with ${ }^{89} \mathrm{Zr}$-trastuzumab and ${ }^{89} \mathrm{Zr}$-bevacizumab. ${ }^{[106,107]}$

Recent studies using magnetic resonance-guided focused ultrasound suggest a role for this noninvasive, radiationfree alternative for treatment of small deep-seated brain metastases. New developments in this field could potentially further expand the treatment spectrum. ${ }^{[108-111]}$

For meeting these challenges, interdisciplinary and integrative research strategies must combine clinical investigation, neurological workup, quality of life assessments, neurocognitive testing, imaging, and histological and molecular profiling of tumor tissue to design individualized treatment strategies tailored to patients with CNS metastases. Only then can the full potential of precision therapeutic approaches be exploited for improving outcomes for our patients.

\section{Financial support and sponsorship}

Intramural Funding of the Center for Personalized Medicine (Demonstratorprojekt “CNSMet”).

\section{Conflicts of interest}

There are no conflicts of interest.

\section{REFERENCES}

1. Giordana MT, Cordera S, Boghi A. Cerebral metastases as first symptom of cancer: a clinico-pathologic study. $J$ neurooncol 2000;50:265-73.

2. Johnson JD, Young B. Demographics of brain metastasis. Neurosurgery clinics of North America. Neurosurg Clin $\mathrm{N} \mathrm{Am}$ 1996; 7:337-44.

3. Soffietti R, Cornu P, Delattre JY, Grant R, Graus F, Grisold W, Heimans J, Hildebrand J, Hoskin P, Kalljo M, Krauseneck P, Marosi C, Siegal T, Vecht C. EFNS Guidelines on diagnosis and treatment of brain metastases: report of an EFNS Task Force. European journal of neurology. Eur J Neurol 2006;13:674-81.

4. Posner JB, Chernik NL. Intracranial metastases from systemic cancer. Advances in neurology. Adv Neurol 1978;19:579-92.

5. Percy AK. Neoplasms of the central nervous system: epidemiologic considerations. Neurology 1970;20:398-9.

6. Fox BD, Cheung VJ, Patel AJ, Suki D, Rao G. Epidemiology of metastatic brain tumors. Neurosurg Clin N Am 2011;22:1-6.

7. Nayak L, Lee EQ, Wen PY. Epidemiology of brain metastases. Current oncology reports. Curr Oncol Rep 2012;14:48-54.

8. Margolin K, Ernstoff MS, Hamid O, Lawrence D, McDermott D, Puzanov I, Wolchok JD, Clark JI, Sznol M, Logan TF, Richards J, Michener T, Balogh A, Heller KN, Hodi FS. Ipilimumab in patients with melanoma and brain metastases: an open-label, phase 2 trial. Lancet Oncol 2012;13:459-65.

9. Tsao MN, Lloyd N, Wong RK, Chow E, Rakovitch E, Laperriere N, $\mathrm{Xu}$ W, Sahgal A. Whole brain radiotherapy for the treatment of newly diagnosed multiple brain metastases. Cochrane Database Syst Rev 2012;4:CD003869.

10. Brastianos HC, Cahill DP, Brastianos PK. Systemic therapy of brain metastases. Curr Neurol Neurosci Rep 2015;15:518.

11. Barnholtz-Sloan JS, Sloan AE, Davis FG, Vigneau FD, Lai P, Sawaya RE. Incidence proportions of brain metastases in patients diagnosed (1973 to 2001) in the Metropolitan Detroit Cancer Surveillance System. J Clin Oncol 2004;22:2865-72.

12. Schouten LJ, Rutten J, Huveneers HA, Twijnstra A. Incidence of brain metastases in a cohort of patients with carcinoma of the breast, colon, kidney, and lung and melanoma. Cancer 2002;94:2698-705.

13. Nieder C, Spanne O, Mehta MP, Grosu AL, Geinitz H. Presentation, patterns of care, and survival in patients with brain metastases: what has changed in the last 20 years? Cancer 2011;117:2505-12. 
14. Pestalozzi BC, Brignoli S. Trastuzumab in CSF. J Clin Oncol 2000;18:2349-51.

15. Bria E, Cuppone F, Fornier M, Nistico C, Carlini P, Milella M, Sperduti I, Terzoli E, Cognetti F, Giannarelli D. Cardiotoxicity and incidence of brain metastases after adjuvant trastuzumab for early breast cancer: the dark side of the moon? A meta-analysis of the randomized trials. Breast Cancer Res Treat 2008;109:231-9.

16. Chamberlain MC. Neoplastic meningitis. Curr Neurol Neurosci Rep 2008;8:249-58.

17. Chamberlain MC. Neoplastic meningitis and metastatic epidural spinal cord compression. Hematol Oncol Clin North Am 2012;26:917-31.

18. Winkler F. The brain metastatic niche. J Mol Med 2015;93:1213-20.

19. Kienast $\mathrm{Y}$, von Baumgarten L, Fuhrmann M, Klinkert WE, Goldbrunner R, Herms J, Winkler F. Real-time imaging reveals the single steps of brain metastasis formation. Nat Med 2010;16:116-22.

20. Kodack DP, Chung E, Yamashita H, Incio J, Duyverman AM, Song Y, Farrar CT, Huang Y, Ager E, Kamoun W, Goel S, Snuderl M, Lussiez A, Hiddingh L, Mahmood S, Tannous BA, Eichler AF, Fukumura D, Engelman JA, Jain RK. Combined targeting of HER2 and VEGFR2 for effective treatment of HER2-amplified breast cancer brain metastases. Proc Natl Acad Sci U S A 2012;109:E3119-27.

21. Fidler IJ, Balasubramanian K, Lin Q, Kim SW, Kim SJ. The brain microenvironment and cancer metastasis. Mol Cells 2010;30:93-8.

22. Park ES, Kim SJ, Kim SW, Yoon SL, Leem SH, Kim SB, Kim SM, Park YY, Cheong JH, Woo HG, Mills GB, Fidler IJ, Lee JS. Crossspecies hybridization of microarrays for studying tumor transcriptome of brain metastasis. Proc Natl Acad Sci U S A 2011;108:17456-61.

23. Zhang L, Zhang S, Yao J, Lowery FJ, Zhang Q, Huang WC, Li P, Li M, Wang X, Zhang C, Wang H, Ellis K, Cheerathodi M, McCarty JH, Palmieri D, Saunus J, Lakhani S, Huang S, Sahin AA, Aldape KD, Steeg PS, Yu D. Microenvironment-induced PTEN loss by exosomal microRNA primes brain metastasis outgrowth. Nature 2015;527:100-4.

24. Galon J, Mlecnik B, Bindea G, Angell HK, Berger A, Lagorce C, Lugli A, Zlobec I, Hartmann A, Bifulco C, Nagtegaal ID, Palmqvist R, Masucci GV, Botti G, Tatangelo F, Delrio P, Maio M, Laghi L, Grizzi F, Asslaber M, D’Arrigo C, Vidal-Vanaclocha F, Zavadova E, Chouchane L, Ohashi PS, Hafezi-Bakhtiari S, Wouters BG, Roehrl M, Nguyen L, Kawakami Y, Hazama S, Okuno K, Ogino S, Gibbs P, Waring P, Sato N, Torigoe T, Itoh K, Patel PS, Shukla SN, Wang Y, Kopetz S, Sinicrope FA, Scripcariu V, Ascierto PA, Marincola FM, Fox BA, Pagès F. Towards the introduction of the 'Immunoscore' in the classification of malignant tumours. J Pathol 2014;232:199-209.

25. Li W, Graeber MB. The molecular profile of microglia under the influence of glioma. Neuro Oncol 2012;14:958-78.

26. Bienkowski M, Preusser M. Prognostic role of tumour-infiltrating inflammatory cells in brain tumours: literature review. Curr Opin Neurol 2015;28:647-58

27. Szulzewsky F, Pelz A, Feng X, Synowitz M, Markovic D, Langmann T, Holtman IR, Wang X, Eggen BJ, Boddeke HW, Hambardzumyan D, Wolf SA, Kettenmann H. Glioma-associated microglia/macrophages display an expression profile different from M1 and M2 polarization and highly express Gpnmb and Spp1. PLoS One 2015;10:e116644.

28. Niessner H, Forschner A, Klumpp B, Honegger JB, Witte M, Bornemann A, Dummer R, Adam A, Bauer J, Tabatabai G, Flaherty K, Sinnberg T, Beck D, Leiter U, Mauch C, Roesch A, Weide B, Eigentler T, Schadendorf D, Garbe C, Kulms D, Quintanilla-Martinez L, Meier F. Targeting hyperactivation of the AKT survival pathway to overcome therapy resistance of melanoma brain metastases. Cancer Med 2013;2:76-85.

29. Chen G, Chakravarti N, Aardalen K, Lazar AJ, Tetzlaff MT, Wubbenhorst B, Kim SB, Kopetz S, Ledoux AA, Gopal YN, Pereira CG, Deng W, Lee JS, Nathanson KL, Aldape KD, Prieto VG, Stuart D, Davies MA. Molecular profiling of patient-matched brain and extracranial melanoma metastases implicates the PI3K pathway as a therapeutic target. Clin Cancer Res 2014;20:5537-46.
30. Saunus JM, Quinn MC, Patch AM, Pearson JV, Bailey PJ, Nones K, McCart Reed AE, Miller D, Wilson PJ, Al-Ejeh F, Mariasegaram M, Lau Q, Withers T, Jeffree RL, Reid LE, Da Silva L, Matsika A, Niland CM, Cummings MC, Bruxner TJ, Christ AN, Harliwong I, Idrisoglu S, Manning S, Nourse C, Nourbakhsh E, Wani S, Anderson MJ, Fink JL, Holmes O, Kazakoff S, Leonard C, Newell F, Taylor D, Waddell N, Wood S, Xu Q, Kassahn KS, Narayanan V, Taib NA, Teo SH, Chow YP, kConFab, Jat PS, Brandner S, Flanagan AM, Khanna KK, Chenevix-Trench G, Grimmond SM, Simpson PT, Waddell $\mathrm{N}$, Lakhani SR. Integrated genomic and transcriptomic analysis of human brain metastases identifies alterations of potential clinical significance. J Pathol 2015;237:363-78.

31. El-Deiry WS, Vijayvergia N, Xiu J, Scicchitano A, Lim B, Yee NS, Harvey HA, Gatalica Z, Reddy S. Molecular profiling of 6,892 colorectal cancer samples suggests different possible treatment options specific to metastatic sites. Cancer Biol Ther 2015;16:1726-37.

32. Lin NU, Lee EQ, Aoyama H, Barani IJ, Barboriak DP, Baumert BG, Bendszus M, Brown PD, Camidge DR, Chang SM, Dancey J, de Vries EG, Gaspar LE, Harris GJ, Hodi FS, Kalkanis SN, Linskey ME, Macdonald DR, Margolin K, Mehta MP, Schiff D, Soffietti R, Suh JH, van den Bent MJ, Vogelbaum MA, Wen PY. Response assessment criteria for brain metastases: proposal from the RANO group. Lancet Oncol 2015;16:e270-8.

33. Okada H, Weller M, Huang R, Finocchiaro G, Gilbert MR, Wick W, Ellingson BM, Hashimoto N, Pollack IF, Brandes AA, Franceschi E, Herold-Mende C, Nayak L, Panigrahy A, Pope WB, Prins R, Sampson JH, Wen PY, Reardon DA. Immunotherapy response assessment in neuro-oncology: a report of the RANO working group. Lancet Oncol 2015;16:e534-42.

34. Kang TW, Kim ST, Byun HS, Jeon P, Kim K, Kim H, Lee JI. Morphological and functional MRI, MRS, perfusion and diffusion changes after radiosurgery of brain metastasis. Eur $J$ Radiol 2009; $72: 370-80$

35. Hoefnagels FW, Lagerwaard FJ, Sanchez E, Haasbeek CJ, Knol DL, Slotman BJ, Vandertop WP. Radiological progression of cerebral metastases after radiosurgery: assessment of perfusion MRI for differentiating between necrosis and recurrence. $J$ Neurol 2009;256:878-87.

36. Kruger S, Mottaghy FM, Buck AK, Maschke S, Kley H, Frechen D, Wibmer T, Reske SN, Pauls S. Brain metastasis in lung cancer. Comparison of cerebral MRI and 18F-FDG-PET/CT for diagnosis in the initial staging. Nuklearmedizin 2011;50:101-6.

37. Terakawa Y, Tsuyuguchi N, Iwai Y, Yamanaka K, Higashiyama S, Takami T, Ohata K. Diagnostic accuracy of 11C-methionine PET for differentiation of recurrent brain tumors from radiation necrosis after radiotherapy. $J$ Nucl Med 2008;49:694-9.

38. Grosu AL, Astner ST, Riedel E, Nieder C, Wiedenmann N, Heinemann F, Schwaiger M, Molls M, Wester HJ, Weber WA. An interindividual comparison of O-(2-[18F]fluoroethyl)-L-tyrosine (FET)- and L-[methyl-11C]methionine (MET)-PET in patients with brain gliomas and metastases. Int J Radiat Oncol Biol Phys 2011;81:1049-58.

39. Connell JJ, Chatain G, Cornelissen B, Vallis KA, Hamilton A, Seymour L, Anthony DC, Sibson NR. Selective permeabilization of the blood-brain barrier at sites of metastasis. J Natl Cancer Inst 2013; 105:1634-43

40. Gaspar L, Scott C, Rotman M, Asbell S, Phillips T, Wasserman T, McKenna WG, Byhardt R. Recursive partitioning analysis (RPA) of prognostic factors in three Radiation Therapy Oncology Group (RTOG) brain metastases trials. Int $J$ Radiat Oncol Biol Phys 1997;37:745-51

41. Sperduto PW, Berkey B, Gaspar LE, Mehta M, Curran W. A new prognostic index and comparison to three other indices for patients with brain metastases: an analysis of 1,960 patients in the RTOG database. Int J Radiat Oncol Biol Phys 2008;70:510-4. 
42. Sperduto PW, Kased N, Roberge D, Xu Z, Shanley R, Luo X, Sneed PK, Chao ST, Weil RJ, Suh J, Bhatt A, Jensen AW, Brown PD, Shih HA, Kirkpatrick J, Gaspar LE, Fiveash JB, Chiang V, Knisely JP, Sperduto CM, Lin N, Mehta M. Effect of tumor subtype on survival and the graded prognostic assessment for patients with breast cancer and brain metastases. Int J Radiat Oncol Biol Phys 2012;82:2111-7.

43. Sperduto PW, Kased N, Roberge D, Xu Z, Shanley R, Luo X, Sneed PK, Chao ST, Weil RJ, Suh J, Bhatt A, Jensen AW, Brown PD, Shih HA, Kirkpatrick J, Gaspar LE, Fiveash JB, Chiang V, Knisely JP, Sperduto CM, Lin N, Mehta M. Summary report on the graded prognostic assessment: an accurate and facile diagnosis-specific tool to estimate survival for patients with brain metastases. J Clin Oncol 2012;30:419-25.

44. Herrlinger U, Forschler H, Kuker W, Meyermann R, Bamberg M, Dichgans J, Weller M. Leptomeningeal metastasis: survival and prognostic factors in 155 patients. J Neurol Sci 2004;223:167-78.

45. Chamberlain MC, Johnston SK, Glantz MJ. Neoplastic meningitisrelated prognostic significance of the Karnofsky performance status. Arch Neurol 2009;66:74-8.

46. Jaeckle KA. Neoplastic meningitis from systemic malignancies: diagnosis, prognosis and treatment. Semin Oncol 2006;33:312-23.

47. Venur VA, Ahluwalia MS. Prognostic scores for brain metastasis patients: use in clinical practice and trial design. Chin Clin Oncol 2015;4:18.

48. Eigentler TK, Figl A, Krex D, Mohr P, Mauch C, Rass K, Bostroem A, Heese O, Koelbl O, Garbe C, Schadendorf D. Number of metastases, serum lactate dehydrogenase level, and type of treatment are prognostic factors in patients with brain metastases of malignant melanoma. Cancer 2011;117:1697-703.

49. Marcus DM, Lowe M, Khan MK, Lawson DH, Crocker IR, Shelton JW, Melton A, Maynard N, Delman KA, Carlson GW, Rizzo M. Prognostic factors for overall survival after radiosurgery for brain metastases from melanoma. Am J Clin Oncol 2014;37:580-4.

50. Spanberger T, Berghoff AS, Dinhof C, Ilhan-Mutlu A, Magerle M, Hutterer M, Pichler J, Wohrer A, Hackl M, Widhalm G, Hainfellner JA, Dieckmann K, Marosi C, Birner P, Prayer D, Preusser M. Extent of peritumoral brain edema correlates with prognosis, tumora growth pattern, HIF1a expression and angiogenic activity in patients with single brain metastases. Clin Exp Metastasis 2013;30:357-68.

51. Berghoff AS, Spanberger T, Ilhan-Mutlu A, Magerle M, Hutterer M, Woehrer A, Hackl M, Widhalm G, Dieckmann K, Marosi C, Birner P, Prayer D, Preusser M. Preoperative diffusion-weighted imaging of single brain metastases correlates with patient survival times. PLoS One 2013;8:e55464.

52. Zakaria R, Das K, Radon M, Bhojak M, Rudland PR, Sluming V, Jenkinson MD. Diffusion-weighted MRI characteristics of the cerebral metastasis to brain boundary predicts patient outcomes. BMC Med Imaging 2014;14:26.

53. Kalkanis SN, Kondziolka D, Gaspar LE, Burri SH, Asher AL, Cobbs CS, Ammirati M, Robinson PD, Andrews DW, Loeffler JS, McDermott M, Mehta MP, Mikkelsen T, Olson JJ, Paleologos NA, Patchell RA, Ryken TC, Linskey ME. The role of surgical resection in the management of newly diagnosed brain metastases: a systematic review and evidence-based clinical practice guideline. J Neurooncol 2010;96:33-43

54. Mintz AH, Kestle J, Rathbone MP, Gaspar L, Hugenholtz H, Fisher B, Duncan G, Skingley P, Foster G, Levine M. A randomized trial to assess the efficacy of surgery in addition to radiotherapy in patients with a single cerebral metastasis. Cancer 1996;78:1470-6.

55. Lagerwaard FJ, Levendag PC, Nowak PJ, Eijkenboom WM, Hanssens PE, Schmitz PI. Identification of prognostic factors in patients with brain metastases: a review of 1292 patients. Int J Radiat Oncol Biol Phys 1999;43:795-803.

56. Fife KM, Colman MH, Stevens GN, Firth IC, Moon D, Shannon KF, Harman R, Petersen-Schaefer K, Zacest AC, Besser M, Milton GW,
McCarthy WH, Thompson JF. Determinants of outcome in melanoma patients with cerebral metastases. J Clin Oncol 2004;22:1293-300.

57. Ranasinghe MG, Sheehan JM. Surgical management of brain metastases. Neurosurg Focus 2007;22:E2.

58. Eisner W, Burtscher J, Bale R, Sweeney R, Koppelstatter F, Golaszewski S, Kolbitsch C, Twerdy K. Use of neuronavigation and electrophysiology in surgery of subcortically located lesions in the sensorimotor strip. J Neurol Neurosurg Psychiatry 2002;72:378-8.

59. Unsgaard G, Selbekk T, Brostrup Muller T, Ommedal S, Torp SH, Myhr G, Bang J, Nagelhus Hernes TA. Ability of navigated 3D ultrasound to delineate gliomas and metastases--comparison of image interpretations with histopathology. Acta Neurochir (Wien) 2005; 147:1259-69; discussion 1269.

60. Kamp MA, Grosser P, Felsberg J, Slotty PJ, Steiger HJ, Reifenberger G, Sabel M. 5-aminolevulinic acid (5-ALA)-induced fluorescence in intracerebral metastases: a retrospective study. Acta Neurochir (Wien) 2012;154:223-8; discussion 228.

61. Patchell RA, Tibbs PA, Walsh JW, Dempsey RJ, Maruyama Y, Kryscio RJ, Markesbery WR, Macdonald JS, Young B. A Randomized Trial of Surgery in the Treatment of Single Metastases to the Brain. N Engl J Med 1990 22;322:494-500.

62. Vecht CJ, Haaxma-Reiche H, Noordijk EM, Padberg GW, Voormolen JH, Hoekstra FH, Tans JT, Lambooij N, Metsaars JA, Wattendorff AR, Ronald Brand, Jo Hermans. Treatment of single brain metastasis: radiotherapy alone or combined with neurosurgery? Ann Neurol 1993;33:583-90

63. Bindal RK, Sawaya R, Leavens ME, Lee JJ. Surgical treatment of multiple brain metastases. J Neurosurg 1993;79:210-6.

64. Stark AM, Tscheslog H, Buhl R, Held-Feindt J, Mehdorn HM. Surgical treatment for brain metastases: prognostic factors and survival in 177 patients. Neurosurg Rev 2005;28:115-9.

65. Paek SH, Audu PB, Sperling MR, Cho J, Andrews DW. Reevaluation of surgery for the treatment of brain metastases: review of 208 patients with single or multiple brain metastases treated at one institution with modern neurosurgical techniques. Neurosurgery 2005;56:1021-34;di scussion1021-34.

66. Gulati S, Jakola AS, Nerland US, Weber C, Solheim O. The risk of getting worse: surgically acquired deficits, perioperative complications, and functional outcomes after primary resection of glioblastoma. World Neurosurg 2011;76:572-9.

67. Kocher M, Soffietti R, Abacioglu U, Villa S, Fauchon F, Baumert BG, Fariselli L, Tzuk-Shina T, Kortmann RD, Carrie C, Ben Hassel M, Kouri M, Valeinis E, van den Berge D, Collette S, Collette L, Mueller RP. Adjuvant whole-brain radiotherapy versus observation after radiosurgery or surgical resection of one to three cerebral metastases: results of the EORTC 22952-26001 study. J Clin Oncol 2011;29:134-41.

68. Chang EL, Wefel JS, Hess KR, Allen PK, Lang FF, Kornguth DG, Arbuckle RB, Swint JM, Shiu AS, Maor MH, Meyers CA. Neurocognition in patients with brain metastases treated with radiosurgery or radiosurgery plus whole-brain irradiation: a randomised controlled trial. Lancet Oncol 2009;10:1037-44.

69. Stockham AL, Ahluwalia M, Reddy CA, Suh JH, Kumar A, Vogelbaum MA, Barnett GH, Murphy ES, Chao ST. Results of a questionnaire regarding practice patterns for the diagnosis and treatment of intracranial radiation necrosis after SRS. J Neurooncol 2013;115:469-75.

70. Momose $\mathrm{T}$, Nariai $\mathrm{T}$, Kawabe $\mathrm{T}$, Inaji $\mathrm{M}$, Tanaka $\mathrm{Y}$, Watanabe $\mathrm{S}$, Maehara T, Oda K, Ishii K, Ishiwata K, Yamamoto M. Clinical benefit of $11 \mathrm{C}$ methionine PET imaging as a planning modality for radiosurgery of previously irradiated recurrent brain metastases. Clin Nucl Med 2014;39:939-43.

71. Glantz MJ, Jaeckle KA, Chamberlain MC, Phuphanich S, Recht L, Swinnen LJ, Maria B, LaFollette S, Schumann GB, Cole BF, Howell $\mathrm{SB}$. A randomized controlled trial comparing intrathecal sustained- 
release cytarabine (DepoCyt) to intrathecal methotrexate in patients with neoplastic meningitis from solid tumors. Clin Cancer Res 1999;5:3394-402.

72. Roth P, Wick W, Weller M. Steroids in neurooncology: actions, indications, side-effects. Curr Opin Neurol 2010;23:597-602.

73. Slamon DJ, Clark GM, Wong SG, Levin WJ, Ullrich A, McGuire WL. Human breast cancer: correlation of relapse and survival with amplification of the HER-2/neu oncogene. Science 1987;235:177-82.

74. Pestalozzi BC, Zahrieh D, Price KN, Holmberg SB, Lindtner J, Collins J, Crivellari D, Fey MF, Murray E, Pagani O, Simoncini E, Castiglione-Gertsch M, Gelber RD, Coates AS, Goldhirsch A. Identifying breast cancer patients at risk for Central Nervous System (CNS) metastases in trials of the International Breast Cancer Study Group (IBCSG). Ann Oncol 2006;17:935-44.

75. Clayton AJ, Danson S, Jolly S, Ryder WD, Burt PA, Stewart AL, Wilkinson PM, Welch RS, Magee B, Wilson G, Howell A, Wardley AM. Incidence of cerebral metastases in patients treated with trastuzumab for metastatic breast cancer. Br J Cancer 2004;91:639-43.

76. Pierga JY, Bidard FC, Cropet C, Tresca P, Dalenc F, Romieu G, Campone M, Mahier Ait-Oukhatar C, Le Rhun E, Goncalves A, Leheurteur M, Domont J, Gutierrez M, Cure H, Ferrero JM, Labbe-Devilliers $\mathrm{C}$, Bachelot T. Circulating tumor cells and brain metastasis outcome in patients with HER2-positive breast cancer: the LANDSCAPE trial. Ann Oncol 2013;24:2999-3004.

77. Verma S, Miles D, Gianni L, Krop IE, Welslau M, Baselga J, Pegram M, Oh DY, Dieras V, Guardino E, Fang L, Lu MW, Olsen S, Blackwell K. Trastuzumab emtansine for HER2-positive advanced breast cancer. N Engl J Med 2012;367:1783-91.

78. Krop IE, Lin NU, Blackwell K, Guardino E, Huober J, Lu M, Miles D, Samant M, Welslau M, Dieras V. Trastuzumab emtansine (T-DM1) versus lapatinib plus capecitabine in patients with HER2positive metastatic breast cancer and central nervous system metastases: a retrospective, exploratory analysis in EMILIA. Ann Oncol 2015;26:113-9.

79. Burstein HJ, Sun Y, Dirix LY, Jiang Z, Paridaens R, Tan AR, Awada A, Ranade A, Jiao S, Schwartz G, Abbas R, Powell C, Turnbull K, Vermette J, Zacharchuk C, Badwe R. Neratinib, an irreversible ErbB receptor tyrosine kinase inhibitor, in patients with advanced ErbB2positive breast cancer. J Clin Oncol 2010;28:1301-7.

80. Leone JP, Leone BA. Breast cancer brain metastases: the last frontier. Exp Hematol Oncol 2015;4:33.

81. Wang TJ, Saad S, Qureshi YH, Jani A, Nanda T, Yaeh AM, Rozenblat T, Sisti MB, Bruce JN, McKhann GM, Lesser J, Halmos B, Stoopler $\mathrm{MB}$, Lassman $\mathrm{AB}$, Cheng SK, Isaacson SR. Does lung cancer mutation status and targeted therapy predict for outcomes and local control in the setting of brain metastases treated with radiation? Neuro Oncol 2015;17:1022-8.

82. Pao W, Miller V, Zakowski M, Doherty J, Politi K, Sarkaria I, Singh B, Heelan R, Rusch V, Fulton L, Mardis E, Kupfer D, Wilson R, Kris M, Varmus H. EGF receptor gene mutations are common in lung cancers from "never smokers" and are associated with sensitivity of tumors to gefitinib and erlotinib. Proc Natl Acad Sci U S A 2004;101:13306-11.

83. Shaw AT, Yeap BY, Mino-Kenudson M, Digumarthy SR, Costa DB, Heist RS, Solomon B, Stubbs H, Admane S, McDermott U, Settleman J, Kobayashi S, Mark EJ, Rodig SJ, Chirieac LR, Kwak EL, Lynch TJ, Iafrate AJ. Clinical features and outcome of patients with non-small-cell lung cancer who harbor EML4-ALK. $J$ Clin Oncol 2009;27:4247-53.

84. Varella-Garcia M, Berry LD, Su PF, Franklin WA, Iafrate AJ, Ladanyi M, Camidge DR, Garon EB, Haura EB, Horn L, Khuri FR, Pao W, Rudin CM, Shaw AT, Schiller JH, Kris MG, Johnson BE, Minna JD, Kwiatkowski DJ, Bunn PA. J Clin Oncol 2012;30, No 15_suppl:7589.

85. Togashi Y, Masago K, Masuda S, Mizuno T, Fukudo M, Ikemi Y, Sakamori Y, Nagai H, Kim YH, Katsura T, Mishima M. Cerebrospinal fluid concentration of gefitinib and erlotinib in patients with non-small cell lung cancer. Cancer Chemother Pharmacol 2012;70:399-405.

86. Lee DH, Han JY, Lee HG, Lee JJ, Lee EK, Kim HY, Kim HK, Hong EK, Lee JS. Gefitinib as a first-line therapy of advanced or metastatic adenocarcinoma of the lung in never-smokers. Clin Cancer Res 2005;11:3032-7.

87. Kim JE, Lee DH, Choi Y, Yoon DH, Kim SW, Suh C, Lee JS. Epidermal growth factor receptor tyrosine kinase inhibitors as a first-line therapy for never-smokers with adenocarcinoma of the lung having asymptomatic synchronous brain metastasis. Lung Cancer 2009;65:351-4.

88. Heon S, Yeap BY, Lindeman NI, Joshi VA, Butaney M, Britt GJ, Costa DB, Rabin MS, Jackman DM, Johnson BE. The impact of initial gefitinib or erlotinib versus chemotherapy on central nervous system progression in advanced non-small cell lung cancer with EGFR mutations. Clin Cancer Res 2012;18:4406-14.

89. Welsh JW, Komaki R, Amini A, Munsell MF, Unger W, Allen PK, Chang JY, Wefel JS, McGovern SL, Garland LL, Chen SS, Holt J, Liao Z, Brown P, Sulman E, Heymach JV, Kim ES, Stea B. Phase II trial of erlotinib plus concurrent whole-brain radiation therapy for patients with brain metastases from non-small-cell lung cancer. $J$ Clin Oncol 2013;31:895-902.

90. Shaw AT, Kim DW, Nakagawa K, Seto T, Crino L, Ahn MJ, De Pas T, Besse B, Solomon BJ, Blackhall F, Wu YL, Thomas M, O’Byrne KJ, Moro-Sibilot D, Camidge DR, Mok T, Hirsh V, Riely GJ, Iyer S, Tassell V, Polli A, Wilner KD, Jänne PA. $N$ Engl J Med 2013;368:2385-94

91. Solomon BJ, Mok T, Kim DW, Wu YL, Nakagawa K, Mekhail T, Felip E, Cappuzzo F, Paolini J, Usari T, Iyer S, Reisman A, Wilner $\mathrm{KD}$, Tursi J, Blackhall F. First-line crizotinib versus chemotherapy in ALK-positive lung cancer. N Engl J Med 2014;371:2167-77.

92. Soda M, Choi YL, Enomoto M, Takada S, Yamashita Y, Ishikawa S, Fujiwara S, Watanabe H, Kurashina K, Hatanaka H, Bando M, Ohno S, Ishikawa Y, Aburatani H, Niki T, Sohara Y, Sugiyama Y, Mano H. Identification of the transforming EML4-ALK fusion gene in nonsmall-cell lung cancer. Nature 2007;448:561-6.

93. Costa DB, Kobayashi S, Pandya SS, Yeo WL, Shen Z, Tan W, Wilner $\mathrm{KD}$. CSF concentration of the anaplastic lymphoma kinase inhibitor crizotinib. J Clin Oncol 2011;29:e443-5.

94. Costa DB, Shaw AT, Ou SH, Solomon BJ, Riely GJ, Ahn MJ, Zhou C, Shreeve SM, Selaru P, Polli A, Schnell P, Wilner KD, Wiltshire R, Camidge DR, Crino L. Clinical Experience With Crizotinib in Patients With Advanced ALK-Rearranged Non-Small-Cell Lung Cancer and Brain Metastases. J Clin Oncol 2015;33:1881-8.

95. Falk AT, Poudenx M, Otto J, Ghalloussi H, Barrière J. Adenocarcinoma of the lung with miliary brain and pulmonary metastases with echinoderm microtubule-associated protein like 4-anaplastic lymphoma kinase translocation treated with crizotinib: a case report. Lung Cancer 2012;78:282-4.

96. Flaherty KT, Puzanov I, Kim KB, Ribas A, McArthur GA, Sosman JA, O'Dwyer PJ, Lee RJ, Grippo JF, Nolop K, Chapman PB. Inhibition of mutated, activated BRAF in metastatic melanoma. $N$ Engl J Med 2010;363:809-19.

97. Dummer R, Goldinger SM, Turtschi CP, Eggmann NB, Michielin O, Mitchell L, Veronese L, Hilfiker PR, Felderer L, Rinderknecht JD. Vemurafenib in patients with BRAF(V600) mutation-positive melanoma with symptomatic brain metastases: final results of an open-label pilot study. Eur J Cancer 2014;50:611-21.

98. Kim DW, Barcena E, Mehta UN, Rohlfs ML, Kumar AJ, PenasPrado M, Kim KB. Prolonged survival of a patient with metastatic leptomeningeal melanoma treated with BRAF inhibition-based therapy: a case report. BMC cancer 2015;15:400.

99. Gibney GT, Gauthier G, Ayas C, Galebach P, Wu EQ, Abhyankar S, Reyes C, Guerin A, Yim YM. Treatment patterns and outcomes in BRAF V600E-mutant melanoma patients with brain metastases 
receiving vemurafenib in the real-world setting. Cancer Med 2015;4:1205-13

100. Long GV, Trefzer U, Davies MA, Kefford RF, Ascierto PA, Chapman PB, Puzanov I, Hauschild A, Robert C, Algazi A, Mortier L, Tawbi H, Wilhelm T, Zimmer L, Switzky J, Swann S, Martin AM, Guckert M, Goodman V, Streit M, Kirkwood JM, Schadendorf D. Dabrafenib in patients with Val600Glu or Val600Lys BRAF-mutant melanoma metastatic to the brain (BREAK-MB): a multicentre, open-label, phase 2 trial. Lancet Oncol 2012;13:1087-95.

101. Ramanujam S, Schadendorf D, Long GV. Systemic therapies for melanoma brain metastases: which drug for whom and when? Chin Clin Oncol 2015;4:25.

102. Robert C, Thomas L, Bondarenko I, O’Day S, Weber J, Garbe C, Lebbe C, Baurain JF, Testori A, Grob JJ, Davidson N, Richards J, Maio M, Hauschild A, Miller WH, Jr., Gascon P, Lotem M, Harmankaya K, Ibrahim R, Francis S, Chen TT, Humphrey R, Hoos A, Wolchok JD. Ipilimumab plus dacarbazine for previously untreated metastatic melanoma. N Engl J Med 2011;364:2517-26.

103. Hodi FS, O’Day SJ, McDermott DF, Weber RW, Sosman JA, Haanen JB, Gonzalez R, Robert C, Schadendorf D, Hassel JC, Akerley W, van den Eertwegh AJ, Lutzky J, Lorigan P, Vaubel JM, Linette GP, Hogg D, Ottensmeier CH, Lebbe C, Peschel C, Quirt I, Clark JI, Wolchok JD, Weber JS, Tian J, Yellin MJ, Nichol GM, Hoos A, Urba WJ. Improved survival with ipilimumab in patients with metastatic melanoma. N Engl J Med 2010;363:711-23.

104. Brown ES, D JW, Frol A, Bobadilla L, Khan DA, Hanczyc M, Rush AJ, Fleckenstein J, Babcock E, Cullum CM. Hippocampal volume, spectroscopy, cognition, and mood in patients receiving corticosteroid therapy. Biol Psychiatry 2004;55:538-45.

105. Brown ES. Effects of glucocorticoids on mood, memory, and the hippocampus. treatment and preventive therapy. Ann N Y Acad Sci 2009;1179:41-55.

106. Dijkers EC, Oude Munnink TH, Kosterink JG, Brouwers AH, Jager PL, de Jong JR, van Dongen GA, Schroder CP, Lub-de Hooge MN, de Vries EG. Biodistribution of 89Zr-trastuzumab and PET imaging of HER2-positive lesions in patients with metastatic breast cancer. Clin Pharmacol Ther 2010;87:586-92.

107. Gaykema SB, Brouwers AH, Lub-de Hooge MN, Pleijhuis RG, Timmer-Bosscha H, Pot L, van Dam GM, van der Meulen SB, de Jong JR, Bart J, de Vries J, Jansen L, de Vries EG, Schroder CP. 89Zr-bevacizumab PET imaging in primary breast cancer. $J$ Nucl Med 2013;54:1014-8.

108. Lipsman N, Mainprize TG, Schwartz ML, Hynynen K, Lozano AM. Intracranial applications of magnetic resonance-guided focused ultrasound. Neurotherapeutics 2014;11:593-605.

109. Kobus T, McDannold N. Update on Clinical Magnetic ResonanceGuided Focused Ultrasound Applications. Magn Reson Imaging Clin N Am 2015;23:657-67.

110. Werner B, Martin E. Transcranial focused ultrasound : Neurological applications of magnetic resonance-guided high-intensity focused ultrasound. Radiologe 2015;55:976-80,982-3.

111. Ba JL, Jandial R, Nesbit A, Badie B, Chen M. Current and emerging treatments for brain metastases. Oncology 2015;29:250-7. 